\title{
Anxious Encounters with the (Monstrous) Other: The Yakshi Tales of Medieval Kerala
}

\author{
Meenu B. \\ Department of English, Amrita School of Arts and Sciences, Amrita ViswaVidyapeetham, \\ Kochi Campus.ORCID: oooo-0oo2-9141-3921. \\ Email: beingmeenu@gmail.com
}

\begin{abstract}
Stories about monstrous encounters during travel are ubiquitous in every culture. Scholars see them as figurative representations of the cultural anxiety related to traversing the unknown and the encounter with the "Other". For instance, the early Greek 'monster-on-the-road' tales are often read in the context of the expansion of trade among Greek city-states and the Greek colonization of far flung territories which necessitated going beyond the safety of familiar town boundaries. The Indian epics and folktales also abound with encounters of travellers with supernatural/monstrous beings. Whether it is episodes such as the "YakshaPrasna" in the Mahabharata, or the Bodhisatta's encounter with the Naga and the Yaksha in Buddhist legends, or his encounter with Yakkhinis in the Jataka tales, travel often involved encountering the Dangerous "Other" who had to be defeated/satiated/converted. These early traveller's tales can be read as records of the anxieties regarding expansion/establishment of the Kshatriya hero's kingdom where the wild/primitive outside the bounds of civilization had to be conquered/appropriated. In the case of the religious hero, the monster represented a crisis of faith - either he/she was an embodiment of the allures of material pleasure the ascetic had to guard against or a staunch believer of another faith who had to be converted/conquered. All these "forgotten" traditions of travel come together in the Yakshi tales of medieval Kerala where a shape-shifting tree spirit haunting lonely pathways evokes memories of the ancient traveller's encounter with the wilderness and its corresponding deities. This paper attempts to read these tales from medieval Kerala against earlier Indian traditions of travel as well as the literal and metaphorical crossings of caste and gender borders that travel entailed during the medieval period.
\end{abstract}

Keywords: monsters, travel, Indian epics, Jataka tales, medieval Kerala, Yakshi tales

The typical Yakshi tale of medieval Kerala begins with a traveller, usually a Namboothiri or a Brahmin man, on his way to a late night Kathakali performance in a far-away temple or a relative's place, meeting a beautiful woman on the deserted pathway at night. The woman wants to have a paan (murukku)and wants to know if the Namboothiri might have some lime with him to spread on the betel leaves she is having with her. The Namboothiri, usually presented in these stories as a lascivious man ready for all kinds of sexual adventures, wastes no time in offering the lime. The woman who acts coy and bashful is impressed by the Namboothiri and wonders if he would like to visit her home which is quite nearby. The Namboothiri is overjoyed to accompany the beautiful woman to her home. This is where the tale changes its tenor as the young woman and the woman's home both undergo a transformation. The woman changes into a Yakshi, a female monster whose fangs bite into the Namboothiri's neck. The woman's home changes into a palm tree, the Yakshi's haunt. The Yakshi doesn't just drink the Namboothiri's blood; she eats him alive

(C) AesthetixMS 2020. This Open Access article is published under a Creative Commons Attribution Non-Commercial 4.o International License (http://creativecommons.org/licenses/by-nc/4.o/), which permits non-commercial re-use, distribution, and reproduction in any medium, provided the original work is properly cited. For citation use the DOI. For commercial re-use, please contact editor@rupkatha.com. 
and leaves his hair and teeth under her palm tree for the next sojourner to learn a wise lesson about the dangers of night travel.

This medieval Yakshi tale of Kerala has a number of cultural specificities that explicitly and implicitly mark the caste and gender codes of the day. However, as a warning tale about travel, it is no different from the innumerable stories about monstrous encounters during travel ubiquitous in every culture. The propelling motive behind the creation of these tales is the cultural anxiety related to traversing the unknown and the encounter with the "Other."

This cultural anxiety has been encoded as monster tales in many ancient civilizations. For instance, in "Monsters and Fear of Highway Travel in Ancient Greece and Rome," Debbie Felton writes that the ancient Greeks and the Romans, afraid of "going beyond the safety of their familiar town boundaries to risk communication with other settlements" used monstrosity as an "expression of anxiety about the dangers of highway travel during a period of urban and Imperial growth and transition." (Felton, 2019, p.68) Stories about monstrous encounters on the roads started circulating during times that saw the expansion of road networks between previously isolated city-states in ancient Greece and all over the Roman Empire. (Felton, p.52). Travel on these roads involved passing through "long stretches of sparsely settled countryside where lone bandits or entire gangs of highway robbers" could easily ambush the travellers. The travellers were robbed or kidnapped and sold into slavery or prostitution or even killed.( Felton, p.54) These fears were reflected in the earliest stories that presented "brutal monstrous creatures" whose main danger lie in the physical threat they posed to the travellers. For instance, many of the monstrous beings that appear in these tales such as "Antaeus, Cacus, the Crommyonian Sow, and Sciron" delighted in "torture and mutilation." (Felton, pp.67-68)

Debbie Felton further states that the myths of Heracles, Theseus and Oedipus have to be read in this context. The adventures of the Greek hero, Heracles, frequently involved taking on monstrous beings that posed a threat to the traveller on the ancient Mediterranean roads. Theseus, another Greek hero, also had side-adventures which involved "clearing the road of dangers awaiting travellers." (Felton, p.61) Another famous Greek hero, Oedipus, is credited with taking on the Sphinx, who blocked the main road to Thebes. All these stories "reflect a significant concern in classical antiquity about the expansion of Greek society past its small-town boundaries and into the territory of the monstrous 'Other." (Felton, p.61)

The Greek heroes' adventures with monsters remind one of the heroes of Indian epics. Indian epics and folktales also abound with encounters of travellers with supernatural/monstrous beings. For instance, Bhima's encounter with Bakasura in Ekachakra can be read in this light where the hero makes Indian roads safe for travellers. However, in the Indian epics and folktales, there is also another kind of encounter - between the Kshatriya hero/religious hero and what has to be called as the "monstrous sacred."(Arumugam, 2019, p.74). While Arumugam uses the term to investigate the ways in which the sacred and the monstrous "intertwine with and feed into each other," I would like to use this term to indicate deities of an older order which appear in the epics and the folktales, which refuse categorisation and in some ways, stand in opposition with the existing religious order. Robert DeCaroli (2004) calls such varied beings as Yakshas/Yakshis and Nagas as spirit-deities "because these deities hold a liminal position between the realms of ghosts (preta, bhüta) and the gods (deva) and frequently seem to share the nature of both"(DeCaroli, p. 89, note 17). They frequently appear in the epics and tales, either as monsters who threaten the lives of the protagonists or as guardians of ancient lands or waters who test the protagonists.

The "YaksaPrasna" is an interesting episode in the Mahabharata where Yudhisthira, the eldest of the Pandavas, has to confront a Yaksha (who is later revealed to be Lord Yama), the 
guardian of a lake, and win back the lives of his brothers. The Yaksha puts Yudhisthira through a set of questions meant to explore his knowledge in Dharma or righteousness. Gail Sutherland in her book The Disguises of the Demon: The Development of the Yaksa in Hinduism and Buddhism (1991), argues that the "encounter with and ultimate homage" to the Yaksha/Yakshi was often a metaphorical depiction of the Kshatriya hero's encounter with wilderness and guardians of ancient grounds. In these myths, Yakshas were "part of a forest sojourn that establishes and reestablishes the sovereignty of the kshatriya heroes and religious champions." Yaksas, as kshetrapalas ("protectors of the field") or dvarapalas ("door guardians" or "keepers of the way"), used to be "signposts on the pilgrimage trial and guardians of ancient, sanctified pools." (Sutherland, 1991, p. 121) She sees the "YaksaPrasna" as the confrontation of the King, the universal ruler, with the guardian of the natural order, the Yaksha, whose realm is the forest and the water that nurtures it. It is also a passing of the baton, so to speak. The Yaksha is a kshetrapalaka; however he is also a local deity. He cannot protect this natural order beyond its limits. The outer limits of this natural order lie "dangerously close to bestiality and abrogation of the order established in the centers of human society" (Sutherland, 1991, p.92). It is the king's duty to step in and maintain the ultimate harmony of these divergent senses of order - he must protect the earth both by protecting the natural order as well as the social order with justice at its guiding principle. Yudhisthira, unlike his brothers, does not violate the rules of the natural order - he does not try to drink the waters of the lake without answering the questions put forward by the Yaksha. He also upholds the principle of social justice by deciding to save his non-uterine brother Nakula over his uterine brothers. This "testing of the hero" is a common motif and fits the "universal paradigm of the heroic encounter with the magical beast, the dragon or the genie - the supreme test of the bravery, humanity, and self-confidence of the noble hero." (Sutherland, 1991, p. 63)

However, this tale can also be read as the necessity for civilization and its new moral order, represented by the King, to acknowledge the wilderness and its deities. The primitive vegetal deities may have been superseded by the gods of the new religions. However, they still hold power and this encounter of the Kshatriya hero with the "monstrous sacred" is an act of negotiation where the vestiges of power these deities hold is acknowledged and appropriated. A version of the same tale is found in the Devadhamma Jataka where the Bodhisatta has to confront a Yaksha, the guardian of a pond and win back the lives of his brothers. The Yaksha (Yakkha in Pali) is converted to Buddhism on the spot. The Yaksha, originally an overlord of local vegetation, is tamed and brought back to civilization where he is then "installed in a symbolic wilderness of his own," and offered flowers, garlands and food (Sutherland, 1991,p. 102, 95). The installation of the Yakkha had a specific signification in Buddhism where it stood for "an active assimilation on the part of the figure of the Buddha (and the institution of Buddhism) of the indispensable dimension of the wilderness, the unexplored, the profusion of nature, and particularly, the bounty associated with the waters in the form of plentiful rainfall." (Sutherland, 1991, p. 95) The "caitya" or the throne that the king erected in these tales was a symbolic depiction of this process that was supposed to confer the tamed yakkha's powers to his patron.

The Yakshi in Buddhism (Yakkhi/Yakkhini in Pali) also has jurisdiction over the wild places and in the Jataka tales, the encounter with the Yakshi usually occurs in the forest or at sea. However, unlike the Yakkha's, the devouring tendencies of the Yakkhi are "strongly sexual as well as alimentary" (Sutherland, 1991, p. 138). Thus, even when the Yaksha/Yakkha and the Yakshi/Yakkhi are treated as metaphors of the "savage/the uncultivated" in the Jatakas, the femaleness of the Yakshi plays a huge part in how she is viewed. In these stories, it is the Yakshi's solitary wanderings, unattended by any man, which lead to her monsterisation. Sutherland 
further believes that the confusion about her identity stems in part from the strangeness of seeing an "undomesticated" woman, that is, as a woman apparently detached from a man for it is the formal attendance upon husband and family that is the unmistakable sign of the "good" woman. Her solitary wanderings divorce her from a safe image of the bound and the maternal and immediately evoke for a chance male beholder the embodiment of sexual license. (Sutherland, 1991, p. 138)

Sutherland's observations are regarding the representation of the Yakshi in both religions, Hinduism and Buddhism. However, this holds special significance in Buddhism where the use of the demonic feminine imagery is in line with the figurative expressions of Buddhist ideals and thought where asceticism is "male and must defend itself rigorously against the seductive demands of, and attachment to, the world of the senses, which is conceived of as female." (Sutherland, 1991, p. 139) The Jataka tales frequently follow this pattern as can be seen in the Telapatta Jataka (no.96) which records the story of the Bodhisatta's journey from Benares to Takkasila through a forest of yakkhas and yakkhinis. The Yakshi tale of medieval Kerala can be seen as following this prototype. In this Jataka tale, the traveller is warned against Yakkhinis who have the powers of illusion to make grandiloquent houses appear in the middle of the road. These Yakkhinis then decorate themselves with celestial ornaments and sweetly invite the travellers into their homes to refresh themselves with a drink of water:

When they have summoned them they give those who come, seats and seduce them with the charm of their wanton beauty. But having excited their lust, they have intercourse with them and then they kill them and eat them while the blood flows. They take hold of the men's aesthetic sense with their beauty, the sense of sound with sweet words and songs, their sense of smell with divine odors, their taste with all kinds of delicious food, their sense of touch with red cushions of supernal softness. (Sutherland, 1991, p. 138)

Unlike in this tale, the Yakshi, in the typical tale in Kerala's folklore, does not sit in her home and call out to the visitor. Rather, she waits on the wayside taking on the appearance of a beautiful young girl/woman. However, like in the Jataka tale, she also invites the man to her "home" which appears as a mansion to the traveller. The Yakshi's origin as a deity of vegetation is more apparent in the case of the folktale in Kerala since she resides in a palm tree that appears as a mansion to the traveller because of her "maya" or powers of illusion.

Such tales are not unique to the Indian subcontinent. There are ancient Greek stories about lamias, "a half-woman, half-serpent shape-shifting monster," who feeds on babies and the flesh and blood of young men (Felton, 2019, pp. 64-65). They also create mansions with her magic and fatten up their victims with food and wine before devouring them. It requires the magic of a true philosopher to see through their tricks in such stories; this role is performed by the Bodhisatta and the sorcerer in the Buddhist and the Yakshi tales of Kerala respectively.(Felton, 2019, p. 64-65).These stories, just like the Jataka tales, express not just the dangers of road travel. These tales, as in the case of the Yakshi tale, are also narratives about the gendered nature of solitary travel. While there are tales about male monsters as well, all these tales feature male protagonists who travel alone. However, a woman found on the way, unaccompanied by a man, cannot be a traveller. She either has to be a Yakshi or a lamia.

There could be another historical reason behind the association of night travel with female monsters. Donna Jordan quotes Kosambi's study which argues that the crossroads were "the original Stone Age sites of the Mother-goddess cults of India, junctions of primitive nomad tracts where the Mothers were normally worshipped." (Jordan, 2012, p. 202) In course of time, 
some of these tracts developed into trade routes, and traders, before starting a journey, made animal sacrifices to the deities at the crossroads promising more if their journey helped them in reaping profit. It was the "travelling merchant's custom to salute, and if possible, sacrifice, to the Mother-goddess encountered during a voyage." (Jordan, 2012, p.202) D.D. Kosambi argues that in order to preach their religion that insisted upon the cessation of blood-sacrifices, Buddhist monks must have frequented these mother goddess cult-spots where sacrifices were most made. These cult spots often used to be at the junctions of great trade routes. (Kosambi, 1983, pp.95-96) Hence, the Yakshas and Yakshis encountered on the crossways in the Jataka tales may be the deities of local cults, especially mother goddess cults, whose use of animal sacrifice (which was anathema to the Buddhist monks), must have resulted in their being cast as cannibalistic/demonic beings.

When we come to the Yakshi of the medieval traveller tales of Kerala, many of the subtexts of these monstrous encounters converge. For instance, the Yakshi's origins as a primitive tree deity is reflected in her residence in a palm tree as well as in the ending of many a Yakshi tale. In the folktales, the Yakshi is often contained by a Mantravadi (sorcerer) by nailing her to a Kanjiram tree (Snakewood tree). However, if, someone removed the nail by accident, the Yakshi could come out of her imprisonment and go back to her old ways. The Yakshi in many of these stories would request the exorcist that she be given a space in a nearby temple and she would thereafter be worshipped as a deity in the outer courtyard of the temple.

When one looks at the particular variant of the Yakshi tale in Kerala, what one sees is that the indices of gender and caste are its warp and woof. This is no accident for when we come to the pre-colonial society of Kerala, it becomes impossible to talk of gender in isolation from caste. In "Malayalam," the erstwhile name used to refer to Kerala, the social order was one based on the "order of janmabhedam ('difference by birth')" where the social status of the individuals was tied up to where they were born in the social hierarchy and castes or jatis were "hierarchically arranged with little or no individual mobility between them." (Devika, 2007, pp.1-2). It was an order in which external signs of compliance from the "lower" jatis were relentlessly wrested by the jati higher up in the hierarchy. The caste at the top of the hierarchy consisted of the Namboothiris or the Kerala Brahmins, who functioned both as "a landowning aristocracy and religious elite." (Devika, p. 120) The unique system of primogeniture in the Namboothiri family allowed only the eldest son referred to as the moos to marry from his own caste. (Devika, 2007, p.121) The women in the Namboothiri community called as Antarjanams ('inner-people') had to observe elaborate seclusion, and when outside their homes, had to be shielded by a cloak (putappu) and a large cadjan umbrella (kuta). (Devika, 2007, p.122)The younger males in the Namboothiri family were expected to seek marital alliances called sambandham with women from the sudra castes like the Nairs or the Ambalavasis as well as from the matrilineal kshatriyas. However, these alliances were considered by the Namboothiris as beyond the domain of kinship (Devika, 2007, p.121).

It is important to keep this socio-cultural background in mind as we approach the medieval traveller tale of the Yakshi in Kerala where the traveller is often a Namboothiri. It is no surprise because as someone belonging to the highest caste in Kerala at the time when caste codes also decided the limits of one's mobility, the Namboothiri was someone who could travel freely. There were other reasons behind the Namboothiri's fondness for travel such as "[t]hat apart from the eldest son, the rest had no rights over the property, that Kerala Brahmins got free food from all the temples, that women from non-brahmin families were ready to enter into relationships with them." (Nair, 2014, p.435) In the Yakshi tale, the beautiful woman (the Yakshi in disguise) who invites the Namboothiri to spend the night at her home usually belonged to the Nair or Ambalavasi (temple services) castes. For instance, in one of the famous Yakshi tales, the Yakshi 
assumes the appearance of a Varier woman (Ambalavasi). Similarly, at the beginning of the meeting, the woman asks for some lime to spread on the betel leaf to have her murukku or paan. In sambandham, the husband who visited the wife's home often gave her gifts of betel leaves and areca nuts for chewing. Gough writes that "the giving of chewing materials between a man and a woman is everywhere in South India associated with courtship or with the first night of marriage." (Gough, 1974, p.359)

The scholar K. S. Prakash mentions how the Yakshis used to trap those Namboothiris who would be hurriedly leaving to meet the women whom they were in a sambandham with (2007, p. 63). Hence one may speculate that the Yakshi tales were perhaps rooted in the social structure of the time when the Namboothiris entered into sambandham with women from the matrilineal castes whose sexuality was then demonised in these tales. It must be remembered that women belonging to the Namboothiri caste, the antharjanams, were forbidden from showing their face in public. Thus, there were all kinds of control on the sexuality of the women belonging to the Namboothiri caste which point to fears about female sexuality and its uncontrollability within their caste. Was this the reason for the demonisation of the sexuality of the women of the matrilineal castes with whom on the one hand the Namboothiris had contractual relationships called sambandham but on the other hand whom they perhaps regarded as bearers of a devouring female sexuality? Were these tales circulated by the conservative Namboothiris of the day who did not want their bloodline to be polluted by miscegenation? (Haridas, 2016, p.95) Were they warning tales meant to caution young men against engaging in sexual adventures outside their home and community? Were they tales circulated by the 'subaltern' women of the day, victims of the higher caste's sexual violence, who were forced to kill their sexual predators in desolate places and attribute the violence to mythical Yakshis? (Haridas, 2016, pp.94-95) Were they tales circulated by women themselves to protect themselves from sexual predators if they ever got lost on the way at night? There is no conclusive answer to the questions.

Jeffrey Jerome Cohen in his path-breaking work Monster Theory(1996) sees the monster as being the embodiment of "a certain cultural moment - of a time, a feeling and a place" (p.4). In the pathways of history, the Yakshi, perhaps, stands as the representative of primitive mother goddess cultures and fertility cults whom different established religions in India tried to control and assimilate the outsider, who even when she was assimilated and transformed still carried traces of that past. Her "wild" sexuality in different established religions was often re-inscribed as part of a benevolent fertility cult, yet the anxiety about the limits of domestication remained in stories where she emerged as the ogress haunting the crossroads.

However, while the monster may be the embodiment of a particular cultural moment, it also has the tendency to return "in slightly different clothing, each time to be read against contemporary social movements or a specific, determining event," where "each reappearance and its analysis" was still "bound in a double act of construction and reconstitution." (Cohen, 1996, p. 5) Thus, the Yakshi reappears in slightly different clothing at a particular historical moment during the medieval period in Kerala when Namboothiris are part of a cultural set up where they have the right to engage into sexual liaisons with women from certain matrilineal communities or from the community of the devadasis. The stories in the Jataka about Yakshis as the ogresses that plagued travellers take on their specific versions in Kerala's folklore where the Namboothiri traveller replaces the Buddhist traveller of the former.

The "pathway" where the monstrous encounter happens in the Yakshi tale is a "liminal" space. This is no accident for as Michael Uebel argues in his essay "Unthinking the Monster: Twelfth Century Responses to Saracan Alterity," "imagining otherness necessarily involves 
constructing the borderlands, the boundary spaces, that contain-in the double sense, to enclose and to include-what is antithetical to the self." (Uebel, 1996, p. 265) However, this alterity is marked by two interesting paradoxes. The first paradox is that "alterity is never radical" for the terms of any binarism presuppose the other for its meaning and in extreme cases, "the absolutely other is somehow integral to the selfsame." (Uebel, 1996, p. 265) Thus, there is not much separating the Kshatriya ruler or the Bodhisatta from the Yaksha/Yakshi they confront and appropriate. The Yaksha guarding the sanctified waters of the forest is a guardian, a ruler. He is no different from King Yudhisthira, the guardian of the social order. Bodhisatta's conversion of the Yakkha may seem like an act of transformation of the "other" and in many of these tales, the Yakkhas act as advocates of the new religious order after their conversion; however, the Yakkha, in these tales, has to be installed in a "caitya" and worshipped thereafter. The Yakshi in the medieval tales of Kerala was often defeated by a sorcerer, but just like the Yakkha in the Buddhist tales, she had to be installed in the outer compound of the temple to be worshipped thereafter as a deity. All these tales thus call into question the categories of the self and the other for while "the monster is an incorporation of the Outside, the Beyond", it is finally an incorporation "of all those loci that are rhetorically placed as distant and distinct but originate Within." (Cohen, 1996, p.8)

According to Michael Uebel, the second paradox arises from the boundary line's "double status as both marker of separation and line of commonality" when he argues that boundaries "simultaneously partition reality, by separating continua into discrete entities, and serve as lines of contiguity that generate a proverbial gray area." (1996, p. 265) The lonely pathway where the Yakshi stands is an in-between space that marks the separation of the known country from the wilderness, whose deity she used to be. However, this pathway is also "a gray area" that is at once the domesticated as well as the wild. The Yakshi as a monster belongs here for monsters are seen as "anomalous hybrids that constantly make and unmake the boundaries separating interiority from exteriority" and are "especially symbolic of displaced, hence threatening, matter" (Uebel, 2019, p. 266). The Bodhisatta, Yudhisthira and the sorcerer who take on the Yakkha/Yaksha/Yakshi are confronting older systems of religious power which have been displaced by newer systems but are still dangerous in the power they contain. As monsters, the Yakshis and the Yakshas also expose the fragility of classificatory boundaries. Yudhisthira gets tested in the laws of dharma, integral to the civilized order, by a guardian of nature thus complicating the distinctions between culture and nature. The Yakshi in the medieval tales is often defeated by the sorcerer, but he also uses the same powers of magic she employs, making it clear that what separates them is a difference of degree and not of kind.

To conclude, in the Yakshi tales of medieval Kerala, a number of forgotten travel traditions come alive. In essence, these stories are about the confrontation with the wild, once sacred and all-powerful, exemplified by the mother-goddess of the crossroads, now cast in the role of the "monstrous sacred." As a reflection of the socio-cultural climate of medieval Kerala, they are also a testament to the fact that mobility has always been circumscribed by other indices such as those of caste and gender.

\section{References}

Arumugam, I. (2019). Gods as Monsters: Insatiable Appetites, Exceeding Interpretations and a Surfeit of Life. In Yasmine Musharbash and Geir Henning Presterudstuen (Eds.), Monster Anthropology: Ethnographic Explorations of Transforming Social Worlds Through Monsters (pp. 51-71). Bloomsbury Academic. 
Cohen, J. J. (1996). Monster Culture (Seven Theses). In Jeffrey Jerome Cohen (Ed.), Monster Theory: Reading Culture (pp. 3-25). Minneapolis: University of Minnesota Press.

DeCaroli, R. (2004). Haunting the Buddha: Indian Popular Religions and the Formation of Buddhism. Oxford University Press.

Devika, J. (2007).Engendering Individuals: The Language of Re-forming in Twentieth Century Keralam. Hyderabad: Orient Longman.

Felton, D. (2019). Monsters and Fear of Highway Travel in Ancient Greece and Rome. In Yasmine Musharbash and Geir Henning Presterudstuen (Eds.), Monster Anthropology: Ethnographic Explorations of Transforming Social Worlds Through Monsters (pp. 51-71). Bloomsbury Academic.

Gough, K. (1974). Nayar: Central Kerala. In David M. Schneider (Ed.), Matrilineal Kinship (pp. 298-384). Berkeley \& Los Angeles: University of California Press.

Haridas, V.V. (2016). Yakshi Sankalpam. Kottayam: S.P.C.S.

Jordan, D. (2012). Sakti's Revolution: Origins and Historiography of Indic Fierce Goddesses. New Delhi: Munshiram Manoharlal Publishers Pvt. Ltd.

Kosambi, D.D. (1983). Myth and Reality: Studies in the Formation of Indian Culture. Mumbai: Popular Prakashan Pvt Ltd.

Nair, K. (2014). Sivasankaran. Pracheena Keralathinte Charithram. Kottayam: DC Books.

Prakash, K.S (2007). Folklore: Kruthiyum Smruthiyum. Rainbow Books.

Ramaswamy, V. (2010). Chaste Widows, Cunning Wives, and Amazonian Warriors: Imaging of Women in Tamil Oral Tradition. Asian Ethnology. 69(1). Retrieved from https://asianethnology.org/downloads/ae/pdf/a1675.pdf

Sutherland, G. H. (1991). The Disguises of the Demon: The Development of the Yaksa in Hinduism and Buddhism. New York: SUNY Press.

Uebel, M. (1996). Unthinking the Monster: Twelfth-Century Responses to Saracen Alterity. In Jeffrey Jerome Cohen (Ed.), Monster Theory: Reading Culture (pp. 264-291). Minneapolis: University of Minnesota Press.

Dr. Meenu B. is working as Assistant Professor and Research Guide in the Department of English, Amrita School of Arts and Sciences, Amrita ViswaVidyapeetham, Kochi Campus. Her Ph.D thesis, from the University of Hyderabad, was titled 'The Woman who Walks the Night: Yakshi as Myth and Metaphor in Kerala's Cultural Imaginary'. Her M.Phil Dissertation was titled "Reformulations and Deletions: The ‘Woman Question' in Select Early South Indian Social Reformist Novels'. 